\title{
Implementasi Royalti Terhadap Pencipta Lagu Berdasarkan Undang-Undang Nomor 28 Tahun 2014 Tentang Hak Cipta
}

\author{
Daffa Okta Permana ${ }^{1}$, Esther Masri ${ }^{2}$, Clara Ignatia Tobing ${ }^{3}$ \\ ${ }^{123}$ Fakultas Hukum, Universitas Bhayangkara Jakarta Raya \\ Email: daffa.okta17@mhs.ubhara.ac.id; ester.masri@dsn.ubharajaya.ac.id; \\ clara.tobing@ubharajaya.ac.id
}

Article info

Received: Oct 20, 2021 Revised: Nop 17, 2021 Accepted: Nop 30, $2021 \quad$ Published: Dec 9, 2021

DOI: https://doi.org/10.31599/krtha.v15i2.793

Keywords : Implementation, Songwriter, Royalty

Abstract : Indonesia is a country that has a thousand islands that have a wide diversity of arts and culture and are rich in ethnic, ethnic, national and religious diversity. The wealth of art and culture is a national potential that must be protected. Intellectual works of artistic and cultural property that can and need to be protected by law. Because this protected artistic and cultural wealth can increase the welfare not only for its creators but also for the nation and state. This study aims to see how the implementation of Law No. 28 of 2014 on Copyright and what legal remedies are if the songwriter does not get his economic rights. This research uses juridical-normative research which is carried out by tracing or analyzing and analyzing theoretical matters concerning principles, conceptions, legal doctrines and norms, library materials or document materials. The results of this study indicate that the implementation of Law Number 28 of 2014 concerning Copyright is still far from good, because there are still many songwriters who do not get royalties from the songs they create, so many songwriters take legal efforts to get royalties from songs. which he created. There is also a need for socialization to songwriters and owners of entertainment venues in order to make it easier to implement this regulation so that it can provide justice for songwriters.

Kata kunci : Implementasi,Pencipta lagu, Royalti

Abstrak : Indonesia merupakan negara yang memiliki seribu kepulauan yang memiliki keanekaragaman seni dan budaya yang begitu luas dan kaya dengan keanekaragaman etnik, suku, bangsa dan agama. Kekayaan seni dan budaya itulah yang merupakan potensi nasional yang harus dilindungi. Karya intelektual dari kekayaan seni dan budaya itulah yang dapat dan perlu dilindungi oleh UndangUndang. Karena kekayaan seni dan budaya yang dilindungi ini dapat meningkatkan kesejahteraan yang tidak hanya bagi penciptanya tetapi juga bagi bangsa dan negara. Penelitian ini bertujuan untuk melihat bagaimana implementasi Undang-Undang Nomor 28 Tahun 2014 tentang Hak Cipta dan bagaimana upaya hukum jika pencipta lagu tidak mendapatkan hak ekonominya. Penelitian ini menggunakan yuridis-normatif yang dilakukan dengan cara menelusuri atau menelaah dan menganalisis hal-hal yang bersifat teoritis yang menyangkut asas, konsepsi, doktrin dan norma hukum, bahan pustaka atau bahan 
dokumen. Hasil penelitian ini menunjukan bahwa implementasi Undang-Undang Nomor 28 Tahun 2014 tentang Hak Cipta masih jauh dari kata baik, karena masih banyak pencipta lagu yang tidak mendapatkan royalti dari lagu yang ia ciptakan, sehingga banyak dari pencipta lagu melakukan upaya hukum demi mendapatkan royalti dari lagu yang ia ciptakan. Perlu sosialisasi juga kepada pencipta lagu dan pemilik tempat hiburan guna mempermudah melaksanakan Peraturan ini sehingga bisa memberikan keadilan bagi pencipta lagu.

\section{PENDAHULUAN}

Indonesia lama dikenal sebagai sebuah negara yang memiliki ribuan pulau dengan beraneka ragam seni dan budaya. Seni dan budaya merupakan potensi nasional yang harus diberikan perlindungan dengan peraturan yang ada. Adanya perlindungan terhadap seni dan budaya bisa memberikan kesejahteraan penciptanya tetapi juga untuk bangsa dan negara untuk meningkatkan perkembangan seni dan budaya yang melibatkan penciptanya. ${ }^{1}$

Pencipta lagu adalah seseorang yang menggunakan inspirasinya untuk menciptakan musik berdasarkan kemampuan ia berpikir, khayalan, kekereatifannya dan keahliannya di dalam sebuah melodi. ${ }^{2}$ Pasal 1 Undang-Undang Nomor 28 Tahun 2014 tentang Hak Cipta menyebutkan : "Hak Cipta ialah hak ekslusif pencipta yang timbul secara otomatis berdasarkan prinsip deklaratif setelah suatu ciptaan diwujudkan dalam bentuk nyata tanpa mengurangi pembatasan sesuai dengan peraturan perundang-undangan. ${ }^{3}$ Musisi butuh pengorbanan untuk berkarya hingga karya tersebut bernilai dan bermanfaat sehingga dapat dinikmati orang banyak. Jika dikaitkan di bidang perdagangan dan industri maka karya tersebut dapat menghasilkan uang bagi para pencipta lagu. Oleh karena nya dibutuhkan instrumen hukum guna melindungi karya pencipta lagu dan memberikan jaminan tersebut dapat menikmati karya dengan aman karena dengan menegakkan apa yang sudah ada di dalam peraturan tersebut para pencipta lagu akan terjamin karyanya. ${ }^{4}$

Perlindungan yang diberikan berupa hak-hak kepemilikan karya yang lebih dari kemampuan intelektual manusia, contohnya hak cipta melindungi ciptaan di bidang seni

\footnotetext{
${ }^{1}$ Ermansyah Djaja, Hukum Kekayaan Intelektual, Jakarta: Sinar Grafika, 2009, hlm. 2

${ }^{2}$ HendraTanu Atmadja, Hak Cipta Musik atau Lagu Jakarta: Universitas Indonesia, 2003, hlm. 55

${ }^{3}$ Pasal 1 angka 1 Undang-Undang Nomor 28 Tahun 2014 tentang Hak Cipta

${ }^{4}$ Sophar Maru Hutagalung, Hak Cipta Kedudukan dan Perannya dalam Pembangunan, Jakarta, 2011,
} hlm 4 
dalam bentuk ekspresi. ${ }^{5}$ Ekspresi ialah bentuk tulisan seperti lirik lagu. bertujuan guna melindungi karya tersebut dari plagiat atau pembajak yang dilakukan orang lain. ${ }^{6}$

Para pencipta lagu memang seharusnya diberikan insentif yang bertujuan untuk memberikan mereka semangat dan produktif dalam menghasilkan sebuah karya yang lebih baik lagi. ${ }^{7}$ Sejalan dengan konsep Hak Kekayaan Intelektual yang merupakan alat guna mengembangkan ekonomi di negara sebagai salah satu sumber devisa. ${ }^{8}$

\section{METODE}

Terdapat 3 metode penelitian menurut Prof. Abdulkadir Muhammad, yaitu: Penelitian hukum normatif, Penelitian hukum normatif-empiris, dan Penelitian hukum empiris.? Untuk mendukung ketiga jenis penelitian tersebut dapat juga digunakan studi kasus hukum. Dalam hal lain, kasus hukum dikonsepkan sebagai peristiwa hukum dan produk hukum. ${ }^{10}$ Penelitian ini kemudian dilakukan dengan pendekatan yuridis normatif yang bersifat deskriptif.

\section{PEMBAHASAN}

\section{Implementasi Royalti Terhadap Pencipta Lagu Berdasarkan Undang-Undang} Nomor 28 Tahun 2014 Tentang Hak Cipta

Perkembangan ekonomi kreatif yang menjadi salah satu andalan Indonesia berkembang sejalan dengan pesatnya teknologi informasi dan komunikasi. Perkembangan ini juga telah menjadi salah satu variabel dalam Undang-Undang tentang Hak Cipta, mengingat teknologi tersebut di satu sisi memiliki peran strategis dalam pengembangan Hak Cipta, tetapi di sisi lain perkembangan itu bisa menjadi alat untuk pelanggaran hukum di bidang ini. $^{11}$

Hak Kekayaan Intelektual atau Intellectual Property Rights (IPR) telah menjadi perhatian yang sangat penting karena memang memberikan kontribusi besar bagi

\footnotetext{
${ }^{5}$ Sudjana. (2021). Potensi Kekayaan Intelektual Dalam Pengembangan Usaha Mikro, Kecil, dan Menengah. Jurnal Hukum Sasana, 7(1). https://doi.org/10.31599/sasana.v7i1.534

${ }^{6}$ Monika Suharyati, 2014, Perlindungan Hukum Terhadap Hak Ekonomi Pemilik Hak Terkait Dalam Undang-Undang Nomor 28 Tabun 2014 Tentang Hak. Cipta, Jurnal Ilmiah Hukum, Vol 5, No 2 (2014) http://jurnal.dpr.go.id/index.php/hukum/article/view/241, diakses pada tanggal 21 Agustus 2021

7 Sinaga, N. A. (2020). Pentingnya Perlindungan Hukum Kekayaan Intelektual Bagi Pembangunan Ekonomi Indonesia. Jurnal Hukum Sasana, 6(2). https://doi.org/10.31599/sasana.v6i2.385

${ }^{8}$ Ibid, hlm 5

${ }_{9}^{9}$ Abdulkadir Muhammad, Hukum dan Penelitian Hukum, Bandung: PT Citra Adya Bakti, 2004, hlm. 52

${ }^{10}$ Ibid., hlm. 39

${ }^{11}$ Sudjana, "Progresivitas Perlindungan Terhadap Pencipta Dalam Mendorong Ekonomi Kreatif Di Indonesia,” Jurnal Ilmiah Kebijakan Hukum Volume 14 (2020): 183-200
} 
kemajuan masyarakat, termasuk di bidang ekonomi, sehingga para investor dan kreator patut mendapatkan penghargaan melalui hak intelektualnya. ${ }^{12}$

Pada tahun 1980-an dunia musik di Indonesia mengalami perkembangan yang pesat, sehingga dunia industri musik dapat menghasilkan suatu usaha bisnis yang sangat menguntungkan. Perkembangan ini membuat banyak sekali pengusaha tertarik untuk memiliki usaha di dunia industri musik. Industri musik rekaman juga membutuhkan adanya pengelolaan royalti atas ciptaan lagu-lagu di dalamnya. Sehingga ini mendorong didirikannya lembaga-lembaga yang bertujuan untuk mengelola dan mengadministrasikan royalti atas pemakaian lagu-lagu.

Atas dasar itulah didirikan lembaga-lembaga yang bertujuan mengelola royalti atas pemakaian lagu-lagu. Pasal 87 Undang-Undang Nomor 28 Tahun 2014 tentang Hak Cipta menjelaskan: "Untuk mendapatkan hak ekonomi setiap Pencipta, Pemegang Hak Cipta, pemilik Hak Terkait menjadi anggota Lembaga Manajemen Kolektif agar dapat menarikan imbalan yang wajar dari pengguna yang memanfaatkan Hak Cipta dan Hak Terkait dalam bentuk layanan publik yang bersifat komersil. ${ }^{13}$

Lembaga Manajemen Kolektif Nasional berfungsi untuk melakukan koordinasi dan mengawasi pengumpulan royalti oleh Lembaga Manajemen Kolektif di bawahnya. Tempat-tempat umum atau kegiatan yang menggunakan musik seperti kafe, karaoke, dan pentas seni nantinya harus membayar royalti yang diatur lembaga ini. Lalu dihimpun, kemudian dikelola dan menyalurkannya kepada para pencipta dan kemudian pada pemilik hak terkait. ${ }^{14}$

Lembaga Manajemen Kolektif Nasional memiliki kewenangan, yaitu mengkoleksi royalti lagu atau musik dari para pengguna komersil sesuai dengan tarif yang ditetapkan dan disahkan dalam putusan Menteri dan mendistribusikan kepada para pemegang hak cipta. $^{15}$

Berdasarkan Pasal 1 angka 24 Undang-Undang Nomor 28 Tahun 2014 tentang Hak Cipta batasan pengguna secara komersil adalah pemanfaatan ciptaan atau produk Hak Terkait yang bertujuan untuk memperoleh keuntungan ekonomi. ${ }^{16}$ Cara perolehan keuntungan ekonomi dapat dilakukan dengan berbagai sumber atau berbayar. Tetapi, kurangnya pemahaman para pengguna akan Hak Cipta mengakibatkan keengganan

\footnotetext{
12 Bernard Nainggolan, Pemberdayaan Hukum Hak Cipta Dan Lembaga Manajemen Kolektif, Alumni, Bandung, 2011.

13 Pasal 87 Undang-Undang Nomor 28 Tahun 2014 Tentang Hak Cipta

14 https://dgip.go.id/lembaga-manajemen-kolektif/ diakses 21/08/2021 pukul 20:43 WIB

15 https://www.lmkn.id/kewenangan/ diakses 21/08/2021 pukul 20:56 WIB

16 Atmoko, D. (2019). Pelaksanaan Perjanjian Serta Perlindungan Hukum Praktek Bisnis Waralaba Di Indonesia. Krtha Bhayangkara, 13(1). https://doi.org/10.31599/krtha.v13i1.14
} 
pengguna untuk membayar royalti. Padahal sejak Undang-Undang Nomor 28 Tahun 2014 tentang Hak Cipta diundangkan telah mengatur pemanfaatan terhadap semua ciptaan dan produk hak terkait yang berlaku untuk warga negara, penduduk, dan badan hukum Indonesia. ${ }^{17}$

Untuk mendukung lebih dalam kajian mengenai pembayaran royalti terhadap pencipta lagu, penelitian ini juga melakukan wawancara dengan Anang Hermansyah selaku Pencipta Lagu dan juga mantan anggota DPR Komisi X Dapil Jawa Timur IV periode $2014-2019 .^{18}$

Mengenai implementasi pembayaran royalti, Anang Hermansyah mengatakan bahwa Undang-Undang ini sudah jelas mengatur tentang hak cipta, terutama untuk pembayaran royalti. Sekarang ini tinggal pelaksanaannya saja yang harus lebih dimaksimalkan lagi dan masih butuh perhatian lebih jauh dari Pemerintah agar para seniman (pencipta lagu) ini mendapatkan hak yang seharusnya ia dapatkan. ${ }^{19}$

Narasumber juga berpendapat kalau penarikan royalti di Indonesia ini harus merata, tidak hanya di kota-kota besar saja, tetapi di kota-kota yang belum terjamah atau jauh dari perkotaan pun harus melakukan penarikan royalti oleh Pemerintah. Maka dari itu narasumber menyarankan agar daerah-daerah tersebut membuat Peraturan Daerah tentang penarikan royalti dari tempat yang bersifat komersil. Karena dengan dibuatnya Peraturan Daerah tersebut akan membantu mensejahterakan para pencipta lagu yang lagunya dimainkan di daerah tersebut, lalu juga dapat membantu Lembaga Manajemen Kolektif dalam menarik royalti dari tempat-tempat yang bersifat komersil di daerah tersebut. $^{20}$

Selain itu, pemahaman Pemerintah terhadap Undang-Undang Hak Cipta sangat dibutuhkan sebagai pihak yang berwenang untuk menjalankan Peraturan ini, begitu juga para pencipta lagu yang perlu memahami Undang-Undang Nomor 28 Tahun 2014 tentang

${ }^{17}$ Noviriska. (2019). Solusi Konflik Hukum Bisnis Dalam Kontrak Kerjasama Antara Agency Model Dan Talent Dengan Para Pihak Pada Industri Entertainment. Krtha Bhayangkara, 13(1). https://doi.org/10.31599/krtha.v13i1.15

18 Wawancara penulis dengan Anang Hermansyah. Pencipta Lagu dan juga mantan anggota DPR dapil Jawa Timur IV, periode 2014-2019 anggota Komisi X, di toko Lumiere, Pondok Indah, 8 Februari 2021. Pukul 15.30 WIB

${ }_{19}$ Wawancara penulis dengan Anang Hermansyah. Pencipta Lagu dan juga mantan anggota DPR dapil Jawa Timur IV, periode 2014-2019 anggota Komisi X, di toko Lumiere, Pondok Indah, 8 Februari 2021. Pukul 15.30 WIB

${ }^{20}$ Wawancara penulis dengan Anang Hermansyah. Pencipta Lagu dan juga mantan anggota DPR dapil Jawa Timur IV, periode 2014-2019 anggota Komisi X, di toko Lumiere, Pondok Indah, 8 Februari 2021. Pukul 15.30 WIB 
Hak Cipta ini agar terciptanya pemahaman terhadap Hak-haknya, dan lebih jauh lagi supaya profesi ini dihargai dan terpenuhi hak yang layak untuk pencipta lagu. ${ }^{21}$

Narasumber berpendapat bahwa Pemerintah perlu melakukan sosialisasi kepada para pencipta lagu mengenai sistem penarikan royalti, karena dengan dilakukannya sosialisasi mengenai penarikan royalti, para pencipta lagu lebih mengerti lagi mengenai Peraturan yang ada dan mereka mendapatkan hasil yang maksimal dari lagu-lagu yang dia ciptakan. $^{22}$

Jika Peraturan ini berjalan dengan baik dan maksimal, maka akan terjadi kondisi saling menguntungkan bagi orang-orang yang terlibat di industri musik maupun dari Pemerintah sendiri. Pencipta lagu mendapatkan royalti, Pemerintah mendapatkan pendapatan pajak dari penarikan royalti dan pengusaha yang menggunakan lagu-lagu dari pencipta lagu bisa menjalankan bisnisnya sampai kapan pun dengan adanya aturan yang jelas dan membayarkan royalti kepada Lembaga Manajemen Kolektif. ${ }^{23}$

Sementara itu, narasumber sempat membahas mengenai permasalahan banyaknya pencipta lagu yang tidak mendapatkan royalti atau royalti tersebut tidak dibayarkan sesuai dengan peraturannya. Menurut narasumber ada permasalahan mengenai kurangnya sosialisasi yang melibatkan pencipta lagu, lembaga manajemen kolektif dan Pemerintah dalam hal pemakaian lagu di ranah publik yang digunakan untuk kepentingan komersil. Karena bila tujuan pemakaian lagu tersebut adalah untuk kepentingan komersil itu maka ada hak yang harus dibayarkan yaitu hak ekonomi dari performing right. ${ }^{24}$

Narasumber berpendapat bahwa dalam industri musik diperlukan sebuah big data. Big data sendiri merupakan kumpulan proses yang terdiri dari volume data dalam jumlah besar yang terstruktur maupun tidak terstruktur dan digunakan untuk membantu kegiatan bisnis. ${ }^{25}$ Big Data ini memiliki posisi penting karena dengan adanya data ini output-nya persoalan royalti menjadi lebih transparan, akuntabel dan ekosistem di industri musik

${ }^{21}$ Wawancara penulis dengan Anang Hermansyah. Pencipta Lagu dan juga mantan anggota DPR dapil Jawa Timur IV, periode 2014-2019 anggota Komisi X, di toko Lumiere, Pondok Indah, 8 Februari 2021. Pukul 15.30 WIB

22 Wawancara penulis dengan Anang Hermansyah. Pencipta Lagu dan juga mantan anggota DPR dapil Jawa Timur IV, periode 2014-2019 anggota Komisi X, di toko Lumiere, Pondok Indah, 8 Februari 2021. Pukul 15.30 WIB

${ }^{3}$ Wawancara penulis dengan Anang Hermansyah. Pencipta Lagu dan juga mantan anggota DPR dapil Jawa Timur IV, periode 2014-2019 anggota Komisi X, di toko Lumiere, Pondok Indah, 8 Februari 2021. Pukul 15.30 WIB

${ }^{24}$ Wawancara penulis dengan Anang Hermansyah. Pencipta Lagu dan juga mantan anggota DPR dapil Jawa Timur IV, periode 2014-2019 anggota Komisi X, di toko Lumiere, Pondok Indah, 8 Februari 2021. Pukul 15.30 WIB WIB

${ }^{25}$ https://www.sekawanmedia.co.id/pengertian-big-data/ Diakses 27/05/2021 Pukul 20.07 
menjadi lebih sehat. ${ }^{26}$ Sedangkan dalam industri kreatif khususnya musik di Indonesia dikenal dengan nama Portamento, Portamento akan mengakomodsi seluruh karya musik di Indonesia sehingga musisi yang mengunggah musik akan muncul keterangan tentang pencipta musik, lirik, rekening bank, nomor wajib pajak, serta segala data tentang musik. Nantinya, Portamento akan terhubung dengan media sosial seperti Youtube dan Facebook serta platform streaming seperti Spotify dan Joox. ${ }^{27}$

Portamento ini sendiri adalah alat untuk mengetahui penggunaan dari lagu tersebut. Misalkan saja bila Rhoma Irama ingin mengetahui lagu Begadang diputar berapa kali dalam waktu sebulan. Nantinya jumlah pemutaran ini akan dideteksi oleh Portamento untuk mengecek lagu yang dinyanyikan, siapa saja yang memakainya, dan besaran royalti yang dia dapatkan. ${ }^{28}$

Sampai saat ini Portamento sendiri ini sedang dikerjakan oleh Badan Ekonomi Kreatif bersama-sama dengan lembaga lainnya. Aplikasi ini sudah dipresentasikan di Organisasi Hak atas Kekayaan Intelektual Dunia atau World Inntelectual Organization (WIPO) di Swiss. Untuk peluncurannya memang tidak bisa cepat karena harus dilakukan testing terlebih dahulu. ${ }^{29}$

Menganai Big Data, narasumber berpendapat bahwa pemerintah wajib membuatnya karena Big Data ini diperlukan untuk collecting dan membagikan royalti kepada pencipta lagu, Big Data inilah yang nantinya akan mencatat musik Indonesia yang ada dari dulu hingga sekarang secara detail. Semua pencipta lagu harus mendaftarkan ke Big Data untuk kepentingan pemberian royalti. Kalau pencipta lagu sudah menjadi bagian dari Lembaga Manajemen Kolektif, Lembaga Manajemen Kolektif harus mengeluarkan data dari pemakaian lagu pencipta lagu tersebut, kalau memang mau mendapatkan royalti. Mengenai aturan hak cipta, di Undang-Undang Nomor 28 Tahun 2014 yang sekarang sudah mengatur pemakaian lagu. Sebenarnya tinggal implementasinya saja untuk menjalankan aturan ini dengan baik, jika sistem yang baik mengenai pemakaian lagu untuk kepentingan komersil, di ranah konser pun sang penyelenggara harus melaporkan lagu

\footnotetext{
${ }^{26}$ https://news.detik.com/berita/d-5522608/pp-royalti-musik-terbit-anang-dorong-jokowirealisasikan-2-lembaga diakses 07/07/2021 Pukul 22:38 WIB

${ }^{27}$ https://www.suarasurabaya.net/infoteknologi/2021/menunggu-portamento-platform-big-datamusik-indonesia/ Diakses 27/05/2021 Pukul 20:21

${ }^{28}$ https://www.alinea.id/gaya-hidup/antara-musisi-cover-portamento-dan-hak-kaum-penciptab1ZVo9xTi Diakses 27/05/2021 Pukul 20:32

${ }^{29} \mathrm{https}$ // www.suarasurabaya.net/infoteknologi/2021/menunggu-portamento-platform-big-datamusik-indonesia/ Diakses 28/05/2021 Pukul 00:39
} 
yang dibawakan kepada Lembaga Manajemen Kolektif Nasional dan membayar royalti tersebut kepada pencipta lagu. ${ }^{30}$

Berdasarkan penjelasan di atas, berikut ini merupakan contoh kasus mengenai pencipta lagu yang tidak mendapatkan royalti atas lagu ciptaannya, antara lain:

\section{Polemik cover lagu Superman Is Dead yang dibawakan Via Vallen}

Pedangdut Via Vallen meng-cover lagu "Sunset di Tanah Anarki" tetapi diketahui tidak adanya izin terlebih dahulu kepada pencipta lagu tersebut. Oleh karena itu drumer Superman Is Dead, Jrinx. Menegur Via Vallen karena dirasa tidak ada itikad baik dengan meminta izin terlebih dahulu. Ketika lagu itu diputar di tv, harus ada tulisan pencipta lagunya, kemudian hak ekonominya dibayarkan ke Wahana Musik Indonesia (WAMI) guna mendapatkan royalti. Karena bagaimanapun juga hak moril akan terus melekat kepada pencipta lagu. ${ }^{31}$

Jika melihat kasus di atas, apa yang dilakukan Jrinx sudah tepat. Sangat tepat. Karena bagaimanapun juga lagu tersebut adalah ciptaan band Superman Is Dead. Merujuk pada Pasal 9 ayat 2 Undang-Undang Nomor 28 Tahun 2014 tentang Hak Cipta yang berbunyi: "Setiap orang yang melaksanakan hak ekonomi sebagaimana dimaksud pada ayat (1) wajib mendapatkan izin Pencipta atau Pemegang Hak Cipta." 32 Dan dilanjutkan dalam Pasal 9 ayat (3) yang berbunyi: “Setiap Orang yang tanpa izin Pencipta atau Pemegang Hak Cipta dilarang melakukan Penggandaan dan/atau Penggunaan Secara Komersial Ciptaan.",33

\section{Perseteruan Cover Lagu “Akad" Payung Teduh dengan Hanin Dhiya}

Vokalis Payung Teduh, Mohammad Istiqamah Djamad atau Is mempermasalahkan tentang artis cover, Hanin Dhiya yang dinilai sudah mengambil keuntungan dari lagu Payung Teduh yang berjudul 'Akad'. Di dalam kasus ini ia mempermasalahkan ada beberapa yang memproduksi lagunya dan sudah dijual di iTunes tanpa seizin pemilik lagu tersebut. $^{34}$

30 Wawancara penulis dengan Anang Hermansyah. Pencipta Lagu dan juga mantan anggota DPR dapil Jawa Timur IV, periode 2014-2019 anggota Komisi X, di toko Lumiere, Pondok Indah, 8 Februari 2021. Pukul 15.30 WIB

${ }^{31}$ https://www.jawapos.com/entertainment/music-movie/18/11/2018/hak-moral-dan-hakekonomi-pencipta-lagu-yang-masih-miris-di-indonesia/ Diakses 28/05/2021 Pukul 22:18 WIB

32 Pasal 9 Ayat (2) Undang-Undang Nomor 28 Tahun 2014 Tentang Hak Cipta

${ }^{33}$ Pasal 9 Ayat (3) Undang-Undang Nomor 28 Tahun 2014 Tentang Hak Cipta

${ }^{34}$ https://www.tribunnews.com/seleb/2017/10/03/vokalis-payung-teduh-kecewa-dengan-hanindhiya-gara-gara-cover-lagu-akad Diakses 29/05/2021 Pukul 21:42 WIB 
Berdasarkan kasus di atas, apa yang dilakukan sang vokalis memang sudah tepat. Karena di dalam Pasal 9 ayat 2 Undang-Undang Nomor 28 Tahun 2014 tentang Hak Cipta yang berbunyi: "Setiap orang yang melaksanakan hak ekonomi sebagaimana dimaksud pada ayat (1) wajib mendapatkan izin Pencipta atau Pemegang Hak Cipta." 35 Dan dilanjutkan di Pasal 9 ayat (3) yang berbunyi: "Setiap Orang yang tanpa izin Pencipta atau Pemegang Hak Cipta dilarang melakukan Penggandaan dan/atau Penggunaan Secara Komersial Ciptaan." 36

\section{Upaya Hukum Apabila Tidak Mendapatkan Royalti}

Pada dasarnya, hak cipta ialah hak untuk menyalin suatu ciptaan. Dengan ini pemegang hak bisa membatasi pemanfaatan atau melakukan pencegahan atas pemanfaatan yang tidak sah terhadap ciptaan. Hak cipta adalah hak yang khusus atau istimewa untuk penciptanya berarti orang lain tidak berhak kecuali ada izin dari si pencipta. ${ }^{37}$ Dalam beberapa kasus banyak sekali hak cipta diambil oleh orang lain sehingga si pencipta tersebut mendapatkan dampak yang kurang baik salah satunya tidak mendapatkan royalti. Untuk itu diperlukan beberapa upaya hukum jika suatu hak cipta digunakan tanpa izin. Upaya untuk pencegahan bisa dilakukan oleh pencipta dengan melakukan pendaftaran terhadap karyanya untuk memperoleh perlindungan kepastian hukum. Jika terjadi sengketa dapat dijadikan bukti di pengadilan. Oleh karena itu penulis akan menjelaskan upaya yang dapat dilakukan oleh pencipta lagu jika terjadi pelanggaran hak cipta. Dalam hukum perdata, penegakan hukum terhadap pelanggaran hak cipta dapat dilihat melalui penerapan Pasal 1365 KUHPerdata yang berbunyi :’Tiap perbuatan melanggar hukum, yang membawa kerugian bagi orang lain, mewajibkan orang yang karena salahnya menerbitkan kerugian itu mengganti kerugian tersebut." ${ }^{38}$ Merujuk Pasal tersebut, maka dalam melakukan gugatan berdasarkan perbuatan melanggar hukum harus dipenuhi syarat dan unsur-unsur perbuatan melawan hukum.

Penyelesaian sengketa dapat dilakukan melalui arbitrase atau pengadilan. Pengadilan Niaga berwenang dalam mengurus penyelesaian sengketa hak cipta. Sebelum melakukan tuntutan pidana penyelesaian dilakukan melalui mediasi (Pasal 95 ayat 1) Undang-Undang Hak Cipta. Pasal 99 ayat 3 dijelaskan bahwa atas permintaan para pihak yang merasa

\footnotetext{
35 Pasal 9 Ayat (2) Undang-Undang Nomor 28 Tahun 2014 Tentang Hak Cipta

36 Pasal 9 Ayat (3) Undang-Undang Nomor 28 Tahun 2014 Tentang Hak Cipta

${ }^{37}$ Leden Marpaung, Tindak Pidana Terbadap Hak atas Kekayaan Intelektual, Jakarta: Sinar Grafika,

38 Kitab Undang-Undang Hukum Perdata 1365
} 1995, hlm 12 
dirugikan akibat pelanggaran hak cipta yang ia punya dan bisa memohon putusan sela dan putusan provisi kepada Pengadilan Niaga : ${ }^{39}$

a. Meminta penyitaan ciptaan yang dilakukan pengumuman atau penggandaan dan/atau alat yang digunakan untuk menghasilkan ciptaan dari hasil pelanggaran hak cipta dan produk terkait.

b. Menghentikan kegiatan pengumuman, pendistribusian, komunikasi, dan/atau penggandaan ciptaan yang merupakan hasil pelanggaran hak cipta.

Upaya lainnya ialah menggunakan delik aduan sesuai pasal 120 Undang-Undang Hak Cipta sehingga dapat dilakukan laporan terlebih dahulu dari pihak yang merasa dirugikan. Penegakan hukum pidana hak cipta lagu diselidiki oleh Penyidik Pejabat Kepolisian Negara Republik Indonesia maupun Pegawai Negeri Sipil di lingkungan kemerntrian di bidang tindak pidana Hak Cipta. Jika pencipta tidak melakukan aduan kepada pihak yang berwajib maka kasus itu tidak akan bisa diproses secara hukum.

Penganturan tentang ancaman pidana terdapat di dalam Pasal 113 Undang-Undang Hak Cipta yang menyebutkan:

1. Setiap orang yang dengan tanpa hak melakukan pelanggaran hak ekonomi sebagaimana dimaksud Pasal 9 (1) huruf i untuk penggunaan secara komersial dipidana dengan pidana penjara paling lama 1 (satu) tahun dan/atau pidana denda paling banyak Rp100.000.000 (seratus juta rupiah)

2. Setiap orang yang dengan tanpa izin pencipta atau pemegang hak cipta melakukan pelanggaran hak ekonomi pencipta sebagaimana dimaksud dalam Pasal 9 ayat (1) huruf c, d, f dan/atau h untuk penggunaan secara komersial dipidana dengan penjara paling lama 3 (tiga) tahun dan/atau pidana denda paling banyak Rp500.000.000,00 (lima ratus juta rupiah)

3. Setiap orang yang dengan tanpa hak dan/atau tanpa izin pencipta atau pemegang hak cipta melakukan pelanggaran hak ekonomi pencipta sebagaimana dimaksud dalam Pasal 9 ayat (1) huruf a, b, c, dan/atau g digunakan untuk secara komersil dipidana dengan pidana paling lama 4 (empat) tahun dan/atau pidana denda paling banyak Rp1.000.000,00 (satu miliar rupiah)

Dengan demikian, setiap orang yang melanggar hak ekonomi dari pencipta lagu dengan cara meng-cover atau dengan cara lain apapun tanpa seizin pencipta lagu akan dikenakan pidana penjara dan/atau pidana denda.

${ }^{39}$ Pasal 95 ayat (3) Undang-Undang Nomor 28 Tahun 2014 tentang Hak Cipta 


\section{KESIMPULAN}

Perkembangan ekonomi kreatif di Indonesia sangat tinggi. Di satu sisi teknologi mempunyai dampak strategis untuk pengembangan hak cipta terutama pada industri musik namu di sisi lain masih banyak pelanggaran hukum. Oleh karena itu, Pemerintah perlu menegaskan peraturan yang ada untuk menopang laju perekonomian rakyat maupun si pencipta lagu. Dengan pesatnya perkembangan ekonomi kreatif khususnya di bidang musik, Lembaga yang mengelola serta mengadministrasikan uang royalti atas pemakaian lagu-lagu berfungsi untuk melakukan koordinasi dan mengawasi pengumpulan royalti yang ada. Kemudian dihimpun, dikelola dan disalurkan kepada para pencipta lagu. Undang-Undang ini sudah jelas mengatur tentang hak cipta, terutama untuk pembayaran royalti. Namun pelaksanaannya harus lebih dimaksimalkan lagi dan masih butuh perhatian lebih jauh dari pemerintah agar para seniman (pencipta lagu) mendapatkan hak yang seharusnya ia peroleh.

Adanya upaya-upaya hukum jika pencipta tak mendapatkan haknya dari lagu ciptaannya ada di Pasal 95 ayat (1) Undang-Undang Hak Cipta yaitu dengan cara arbitrase dan yang berwenang adalah Pengadilan Niaga. Kemudian jika melakukan gugatan secara hukum perdata dapat menggunakan Pasal 1365 KUHPerdata yang mewajibkan memberikan ganti rugi. Namun jika pencipta tersebut merasa dirugikan, ia dapat memohon putusan provisi dan sela kepada Pengadilan Niaga guna melakukan penyitaan dan menghentikan kegiatan distribusi ciptaan dari hasil pelanggaran tersebut. Upaya itu dapat dilakukan pencipta lagu dengan penegakan hukum pidana berdasarkan Pasal 120 Undang-Undang ini dengan delik aduan. Jika melakukan pelanggaran hak ekonomi maka orang tersebut akan dikenakan Pasal 113 Undang-Undang Hak Cipta dan diancam penjara dan denda.

\section{SARAN}

Sebaiknya di dalam peraturan mengenai Hak Cipta dapat diterapkan dengan baik sehingga dapat memberikan dampak konkret terhadap pemberian royalti di Indonesia khususnya bagi pencipta lagu. jika Undang-Undang ini berjalan dengan baik maka akan meminimalisir kejadian seperti pencipta lagu yang tidak mendapatkan hak ekonominya. Lalu diperlukan pemahaman lebih lanjut mengenai aturan ini oleh Pemerintah, Pencipta lagu dan pemilik tempat-tempat komersil agar saling menguntungkan satu sama lain. 
Sebaiknya jika pencipta lagu merasa dirugikan karena ciptaannya digunakan oleh orang lain tanpa izin dan ia tidak mendapatkan hak ekonominya, lebih baik melakukan upaya hukum agar pencipta lagu mendapatkan haknya kembali.

\section{DAFTAR PUSTAKA}

Abdulkadir, Muhammad, 2004, Hukum dan Penelitian Hukum, Bandung: PT Citra Adya Bakti.

Bernard Nainggolan, 2011, Pemberdayaan Hukum Hak Cipta Dan Lembaga Manajemen Kolektif, Alumni, Bandung.

Ermansyah Djaja, 2009, Hukum Kekayaan Intelektual, Sinar Grafika, Jakarta.

HendraTanu Atmadja, 2003, Hak Cipta Musik atau Lagu, Jakarta:Hukum, Universitas Indonesia.

https://dgip.go.id/lembaga-manajemen-kolektif/ diakses 21/08/2021 pukul 20:43 WIB

https://news.detik.com/berita/d-5522608/pp-royalti-musik-terbit-anang-dorongjokowi-realisasikan-2-lembaga diakses 07/07/2021 Pukul 22:38 WIB

https://www.alinea.id/gaya-hidup/antara-musisi-cover-portamento-dan-hak-kaumpencipta-b1ZVo9xTi Diakses 27/05/2021 Pukul 20:32

https://www.jawapos.com/entertainment/music-movie/18/11/2018/hak-moral-danhak-ekonomi-pencipta-lagu-yang-masih-miris-di-indonesia/ Diakses 28/05/2021 Pukul 22:18 WIB

https://www.lmkn.id/kewenangan/ diakses 21/08/2021 pukul 20:56 WIB

https://www.sekawanmedia.co.id/pengertian-big-data/ Diakses 27/05/2021 Pukul 20.07 WIB

https://www.suarasurabaya.net/infoteknologi/2021/menunggu-portamento-platformbig-data-musik-indonesia/ Diakses 27/05/2021 Pukul 20:21

https://www.tribunnews.com/seleb/2017/10/03/vokalis-payung-teduh-kecewadengan-hanin- dhiya-gara-gara-cover-lagu-akad Diakses 29/05/2021 Pukul 21:42 WIB 
KRTHA BHAYANGKARA | Volume 15 Number 2, December 2021

https://www.suarasurabaya.net/infoteknologi/2021/menunggu-portamento-platformbig-data-musik-indonesia/ Diakses 28/05/2021 Pukul 00:39

Monika Suharyati, 2014, Perlindungan Hukum Terhadap Hak Ekonomi Pemilik Hak Terkait Dalam Undang-Undang Nomor 24 Tahun 2014 Tentang Hak Cipta, Jurnal Ilmiah Hukum, Vol 5, No 2 (2014), https://jurnal.dpr.go.id/index.php/hukum/article/view/241, di akses pada tanggal 21 Agustus 2021

Atmoko, D. (2019). Pelaksanaan Perjanjian Serta Perlindungan Hukum Praktek Bisnis Waralaba Di Indonesia. Krtha Bhayangkara, 13(1). https://doi.org/10.31599/krtha.v13i1.14

Noviriska. (2019). Solusi Konflik Hukum Bisnis Dalam Kontrak Kerjasama Antara Agency Model Dan Talent Dengan Para Pihak Pada Industri Entertainment. Krtha Bhayangkara, 13(1). https://doi.org/10.31599/krtha.v13i1.15

Undang-Undang Nomor 28 Tahun 2014 Tentang Hak Cipta

Sophar Maru Hutagalung, 2011, Hak Cipta Kedudukan dan Peranannya dalam Pembangunan, Jakarta.

Sudjana, "Progresivitas Perlindungan Terhadap Pencipta Dalam Mendorong Ekonomi Kreatif Di Indonesia," Jurnal Ilmiah Kebijakan Hukum Volume 14 (2020): 183-200

. (2021). Potensi Kekayaan Intelektual Dalam Pengembangan Usaha Mikro, Kecil, dan Menengah. Jurnal Hukum Sasana, 7(1). https://doi.org/10.31599/sasana.v7i1.534

Sinaga, N. A. (2020). Pentingnya Perlindungan Hukum Kekayaan Intelektual Bagi Pembangunan Ekonomi Indonesia. Jurnal Hukum Sasana, 6(2). https://doi.org/10.31599/sasana.v6i2.385

Wawancara penulis dengan Anang Hermansyah. Pencipta Lagu dan juga mantan anggota DPR dapil Jawa Timur IV, periode 2014-2019 anggota Komisi X, di toko Lumiere, Pondok Indah, 8 Februari 2021. Pukul 15.30 WIB 
KRTHA BHAYANGKARA | Volume 15 Number 2, December 2021 